TULIP: Tulisan Ilmiah Pariwisata

E-ISSN: 2720-9873

Available Online at https://journal.umgo.ac.id/index.php/Tulip/index

Vol. 3, No. 1 Juni 2020

DOI: http://dx.doi.org/10.31314/tulip.3.1.19-26.2020

\title{
PARTISIPASI MASYARAKAT LOKAL DI DAYA TARIK WISATA HUTAN PINUS DI KABUPATEN GORONTALO
}

\section{Srilian Laxmiwaty Dai' ${ }^{1}$ Nur Fadhlyah Usu' ${ }^{2}$, Irma K. Hatibie ${ }^{3}$}

Program Studi Pariwisata, Universitas Muhammadiyah Gorontalo, Indonesia

Email; lyan.laxmiwaty@umgo.ac.id, nurfadhlyahusu@gmail.com

\section{Info Artikel}

Diterima: 20

Mei 2020

Disetujui: 02 Juni 2020

\section{Abstract:}

The Objectives of this research are to figure out the local community involvement in the management and the development of Hutan Pinus Dulamayo Tourist Attraction and to know how to improve the local community involvement. The method of this research is qualitative metode with observation, interview and documentation. The result of this research was the lack of local community involvement in the management and the development of Hutan Pinus Dulamayo Tourist Attraction. The management of this tourist attraction is handled by only some people wich did not give a big multiflier effect to all of the local community in Dulamayo Village.

Keywords: Local Community Involvement, Tourist Attraction.

\begin{abstract}
Abstrak:
Tujuan dari penelitian ini adalah untuk mengetahui keterlibatan masyarakat lokal dalam pengelolaan dan pengembangan Objek Wisata Hutan Pinus Dulamayo dan untuk mengetahui bagaimana meningkatkan keterlibatan masyarakat setempat. Metode penelitian ini adalah metode kualitatif dengan observasi, wawancara dan dokumentasi. Hasil dari penelitian ini adalah kurangnya keterlibatan masyarakat lokal dalam pengelolaan dan pengembangan Objek Wisata Hutan Pinus Dulamayo. Pengelolaan objek wisata ini hanya ditangani oleh beberapa orang saja yang tidak memberikan multiflier effect yang besar kepada seluruh masyarakat lokal di Desa Dulamayo.
\end{abstract}

Kata Kunci: Keterlibatan Masyarakat Lokal, Daya Tarik Wisata

\section{PENDAHULUAN}

Pariwisata merupakan salah satu sektor yang potensial dan mendukung kegiatan perekonomian oleh karena itu dibutuhkan perhatian lebih dalam pembangunan dan pengembangan sektor pariwisata. Sektor pariwisata menciptakan peluang usaha, meningkatkan perekonomian dan dapat memberi implikasi positif dalam mensejahterakan masyarakat khususnya masyarakat lokal di suatu daya tarik wisata. Tidak hanya peningkatan dari sektor ekonomi, pengembangan sektor pariwisata juga dapat berkontribusi besar terhadapa 
berbagai sektor seperti sektor sosial, budaya dan lain sebagainya. Melihat berbagai implikasi positif dari sektor pariwisata, tentunya sangat diharapkan adanya keberlanjutan dalam pengelolaan daya tarik wisata dan destinasi agar ekonomi suatu daerah kondusif dengan masyrakat yang sejahtera. Dengan demikian, maka pembangunan pariwisata harus didasarkan pada kriteria keberlanjutan yang artinya bahwa pembangunan dapat didukung secara ekologi, sosial dan budaya maupun secara ekonomi.

Pembangunan pariwisata yang berkelanjutan menjadi tujuan setiap destinasi wisata yang ada di Indonesia hal tersebut seolah termotivasi dari keberhasilan Bali sebagai destinasi unggulan Indonesia yang meraih kesuksesan melalui sektor pariwisata. Sebagai salah satu destinasi wisata di Indonesia, Provinsi Gorontalo pun melakukan pembangunan pariwisata dengan berbagai konsep yang notabennya mengarah pada peningkatan kesejahteraan masyarakat. Hal tersebut dikarenakan masyarakat adalah unsur yang sangat penting dalam suatu destinasi wisata maupun daya tarik wisata. Pentingnya unsur masyarakat dalam sektor pariwisata ini menjadi alasan dirumuskannya konsep pariwisata berbasis masyarakat. Dalam pengelolaan daya tarik wisata di Gorontalo, penerapan pariwisata berbasis masyarakat telah dilakukan oleh beberapa pengelola daya tarik wisata. Salah satunya adalaha di Daya Tarik Wisata Hutan Pinus Dulamayo. Daya tarik wisata ini terletak di Desa Dulamayo Selatan, Kecamatan Telaga Biru, Kabupaten Gorontalo. Untuk mencapai tempat ini, ada bebarapa alternatif jalan yang bisa dilalui. Salah satunya melalui jalur timur, yakni dari Kota Gorontalo menuju Kabupaten Bone Bolangao, kemudian melawati Desa Tupa dan beberpa desa lainnya. Waktu tempuh dari pusat Kota Gorontalo munuju puncak Hutan Pinus Dulamayo adalah kurang lebih satu jam.

Setelah tiba di Desa Dulamyo Selatan, para pengunjung atau wisatawan dapat memarkirkan kenderaan dan melanjutkan perjalanan ke Hutan Pinus dengan berjalan kaki kurang lebih 30 menit. Para pengunjung tidak perlu tergesa-gesa berjalan karena sejauh mata memandang pengunjung akan disuguhi pemandangan indah yang seketika dapat menghilangkan rasa letih. Di daya tarik wisata ini terdapat berbagai fasilitas yang disediakan oleh masyarakat sekitar seperti kantin yang menyediakan makanan dan minuman, jasa sewa tenda dan perlengkapan kemah yang disediakan dengan harga terjangkau, toilet umum, jasa parkir kenederaan yang aman, spot foto yang bagus dan lain sebagainya.

Sejak daya tarik wisata ini dibuka, pengunjung datang bergantian tiada henti. Fakta tersebut tentunya memberi harapan terhadap kesejahteraan masyarakat desa yang terjamin. Karena jika dilihat sekilas, pengelola dari daya tarik wisata ini adalah masyarakat, masyarakat pula yang melakukan aktivitas pelayanan terhadap wisatawan atau pengunjung seperti yang berjualan di kantin, yang menjaga loket masuk, menjaga parkir dan yang menyewakan tenda. Maka muncullah harapan besar akan kesejahteraan dan peningkatan perekonomian masyarakat sekitar sehingga dapat menyimbangkan pengembangan 
pariwisata yang mengacu pada konsepkonsep pembangunan yang berkelanjutan.

Pada hakekatnya ketika suatu daya tarik wisata dibuka dan dikembangkan di suatu wilayah seharusnya berkontribusi terhadap masyarakat dengan memberikan dampak yang positif baik dari segi sosial, budaya, khususnya ekonomi agar kehidupan masyarakat lebih baik lagi dengan pendapatan yang pasti. Untuk memperoleh dampak positif tersebut, maka masyarakat harus bekerja ssama dan bekerja keras untuk membangun desanya dan daya tarik wisata di desanya. Akan tetapi pada kenyataannya di Desa Dulamayo Selatan belum semua masyarakat dapat merasakan keuntungan dari eksistensi daya tarik wisata dan aktifitas pariwisata di desa mereka. Dampak ekonomi di desa tersebut juga tidak merata pada masyarakat lokal. Hal ini sebenarnya sangat miris karena jumlah pengunjung di Desa Dulamayo Selatan sangat banyak namun belum memberikan dampak ekonomi yang merata kepada masyarakat secara umum. Kurangnya dampak ekonomi yang positif secara merata pada masyarakat lokal, diyakini karena kurangnya partisipapsi dan keterlibatan masyarakat itu sendiri dalam pembangunan, pengelolaan dan pengembangan daya tarik wisata hutan pinus di Desa Dulamayo Selatan. Oleh karena itu perlu diadakan penelitian mengenai "Partisipasi Masyarakat Lokal Di Daya Tarik Wisata Hutan Pinus Di Kabupaten Gorontalo" Berdasarkan latar belakang permasalahan di atas maka dirumuskan beberapa masalah masalah dalam penelitian ini yaitu : (1) Bagaimana keterlibatan masyarakat lokal di Desa Dulamayo Selatan dalam pengelolaan dan pengembangan Daya Tarik Wisata Hutan Pinus? (2) Bagaimana meningkatkan peran masyarakat lokal dalam pengelolaan dan pengembangan Daya Tarik Wisata Hutan Pinus ? Adapun tujuan dari penelitian ini adalah (1) Untuk mengetahui keterlibatan atau peran serta masyarakat lokal dalam pengelolaan dan pengembangan Daya Tarik Wisata Hutan Pinus. (2) Untuk mengetahui cara meningkatkan peran serta atau keterlibatan masyarakat lokal dalam pengelolaan dan pengembangan Daya Tarik Wisata Hutan Pinus.

\section{METODE}

Metode penelitian yang digunakan pada penelitain ini adalah metode kualitatif. Metode ini menjelaskan suatu data secara rinci, jelas dan detail, sehingga metode penelitian ini akan berkaitan dengan pengumpulan data-data baik baik berupa gambar maupun kalimat-kalimat yang bersifat deskriptif. (Sugiono, 2009). Teknik pengumpulan data pada penelitian ini menggunakan 2 segi teknik, yaitu observasi dan wawancara. Dari segi observasi, teknik ini melakukan pengunjungan dan pengamatan pada daya tarik wisata yang menjadi lokasi penelitian yang dalam hal ini adalah Daya Tarik Hutan Pinus Dulamayo. Berikut dari segi wawancara, teknik ini akan melakukan pengumpulan data dengan mewawancarai pengelola daya tarik wisata, tokoh masyarakat dan aparat desa setempat secara mendalam.

\section{HASIL DAN PEMBAHASAN}

a. Partisipasi Masyarakat 
Menurut Hajar at all (2018)

Partisipasi merupakan keterlibatan dari seseorang atau sekelompok orang (masyarakat) secara sadar untuk berkontribusi secara suka rela dalam program pembangunan dan dimulai dari perencanaan, pelaksanaan, monitoring sampai pada tahap evaluasi.

Ada pun prinsip-prinsip partisipatif tersebut adalah sebagai berikut:

1. Cakupan. Cakupan berarti semua orang atau wakil-wakil semua kelompok yang terkena dampak dari hasil-hasil suatu keputusan atau proses proyek pembangunan.

2. Kesetaraan dan kemitraan, setiap orang memiliki keterampilan, kemampuan dan pengetahuan.

Setiap orang juga memiliki hak yang sama untuk menggunakan apa yang mereka miliki tersebut dalam peran mereka sebagai anggota masyarakat.

3. Transparansi atau memiliki keterbukaan sehingga dapat tercipta komunikasi yang baik.

4. Kesetaraan kewenangan yaitu menyeimbangkan kewenangan dan kekuasaan agar tidak terjadi dominasi oleh suatu pihak.

5. Kesetaraan tanggung jawab artinya semua pihak yang terlibat memiliki kesamaan tanggung jawab.

6. Pemberdayaan artinya semua pihak tidak akan terlepas dari kekurangan dan kelebihan. Maka semua pihak dapat saling memberdayakan kelebihannya untuk merbagi dengan pihak lain yang membutuhkan.

7. Kerja sama. Hal ini dibutuhkan agar semua pihak dapat saling bekerja sama untuk saling menutupi kekurangan yang ada.

b. Konsep Daya Tarik Wisata

Menurut Undang-Undang Republik Indonesia No. 10 tahun 2009, tentang kepariwisataan disebutkan bahwa "daya tarik wisata adalah segala sesuatau yang memiliki keunikan, keindahan dan nilai berupa keanekaragaman kekayaan alam, budaya, dan hasil buatan manusia yang menjadi sarana atau tujuan kunjungan wisatawan."

Suwantoro (1997) menyatakan bahwa daya tarik wisata dikelompokkan atas:

1. Daya tarik wisata terdiri dari wisata alam, wisata budaya, wisata minat khusus.

2. Adanya sumber daya yang dapat memberikan rasa senang, indah, nyaman, dan bersih.

3. Tersedianya aksesibilitas untuk dapat menjangkau daya tarik wisata.

4. Adanya ciri khusus yang unik dan jarang ditemui.

5. Tersedianya sarana dan pra sarana untuk penunjang agar dapat memenuhi kebutuhan wisatawan yang berkunjung.

6. Terdapat sumber daya alam yang indah seperti pegunungan, sungai, pantai, hutan dan sebagainya.

Pengelola perorangan dari unsur masyarakat. Belum diresmikan. Masyarakat lain tidak diperbolehkan 
untuk mengelola, Berdasarkan hasil wawancara dengan beberapa pihak terkait di Daya Tarik Wisata Hutan Pinus Dulamayo, diperoleh informasi bahwa mengenai Partisipasi Masyarakat Lokal di Daya Tarik Wisata Hutan Pinus Dulamayo peneliti dapat menyimpulkan bahwa perekonomian di daya tarik wisata hutan pinus memberikan dampak yang baik untuk perekonomian masyarakat di sekitar daya tarik wisata hutan pinus, namun ada beberapa dari masyarakat sekitar hutan pinus tidak memanfaatkan adanya daya tarik wisata itu untuk meningkatkan perekonomian masyarakat karena ada pihak pengelola yang belum mengizinkan masyarakat untuk ikut turun tangan di hutan pinus tersebut. Adapun masyarakat yang mengelola hutan pinus disitu hanyalah orang yang menjaga parkir.

Hutan pinus dulamayo kini semakin banyak kunjungan wisatawan karena semakin tahun hutan pinus semakin di perbaiki. Kawasan yang terbilang masih sangat asri ini harus mendapat perhatian dari masyarakat agar tetap terjaga dan menjadi pariwisata yang berkelanjutan, maka harus di buat peraturan untuk kepada wisatawan yang datang agar dapat membuang sampah pada tempatnya agar tidak mencemari lingkungan di sekitar hutan pinus dulamayo.

Daya tarik wisata hutan pinus ini menawarkan keindahan alam yang sangat memukau dengan udara di pagi hari yang sejuk membuat wisatawan yang datang berkunjung akan merasa nyaman selama berada di hutan pinus ini. Masyarakat di sekitar hutan pinus juga menyediakan banyak spot foto untuk mengabadikan momen para wisatawan di hutan pinus.

\section{Hasil Penelitian}

1. Dari segi cakupan, masyarakat di desa Dulamayo Selatan belum sepenuhnya terlibat. Berdasarkan hasil wawancara secara mendalam, sejauh ini hanya ada beberapa orang yang terlibat. Keterlibatan tersebut hanya merupakan ajakan karena teman baik atau keluarga pengelola. Sistem ini tentunya perlu diubah agar cakupan keterlibatan masyarakat lokal bisa meluas dan merata dengan cara melibatakn semua elemen masyarakat.

2. Kesetaraan dan kemitraan, dari aspek ini belum semua elemen masyarakat menggunakan hak mereka untuk mengeluarkan pendapat atau memasukkan saran dalam rangka membangun daya tarik wisata hutan pinus. Hal tersebut disebabkan belum adanya keterlibatan semua elemen masyarakat lokal dalam pengelolaan daya tarik wisata hutan pinus.

3. Dari aspek transparansi antara para pengelola saat ini memang sudah ada, namun transparansi terhadap pemerintah desa dan masyarakat lainnya masih belum dilaksanakan. Hal tersebut disebabkan belum adanya peran pemerintah desa untuk mengetur dan mengarahkan pengelola saat ini dengan masyarakat lokal di Desa Dulamayo Selatan. 
4. Kesetaraan kewenangan merupakan aspek yang juga belum diimpelmentasikan dalam pengelolaan daya tarik wisata ini. Jika semua elemen masyarakat telah disertakan dalam pengelolaannya maka perlu adanya kesetaraan kewenangan agar pengelolaan dapat dilakukan secara maksimal.

5. Kesetaraan tanggung jawab telah dimiliki oleh pengelola saat ini. Namun lingkup pengelola masih kecil karena pada poin pertama yaitu cakupan, memang belum mencakup semua elemen masyarakat bahkan pemerintah desa.

6. Pemberdayaan artinya semua pihak tidak akan terlepas dari kekurangan dan kelebihan. Ini merupakan hal yang sangat penting karena inti dari pariwisata berbasis masyarakat dimana masyarakat lokal harus dilibatkan sepenuhnya pada pengelolaan dan setiap pengambilan keputusan agar smua bisa merasakan kenikmatan dari dampak positif dibukaya daya tarik wisata di desa mereka. Sebaliknya jika terdapat dampak negatif dengan adanya aktifitas pariwisata di desa mereka, maka mereka akan merasakannya secara bersama dan dapat bersatu memikirkan solusi serta bahu membahu menjadikan desanya lebih baik lagi dan terhindar dari dampak negatif yang mungkin saja terjadi.

Kerja sama. Hal ini memang seharusnya terjadi karena industri pariwisata adalah industri yang bersifat unsubstitutif dimana satu pihak akan membutuhkan pihak lainnya karena usaha-usaha pariwisata tidak dapat saling menggantikan. Misalnya pengelola suatu daya tarik wisata akan membutuhkan usaha rumah makan atau warung makan agar wisatawan yang perlu makanan bisa membelinya di dalam daya tarik wisata atau di sekitar daya tarik wisata. Pengelola juga akan butuh transportasi umum agar wisatawan yang berkunjung yang membutuhkan jasa transportasi umum dapat memperoleh akses transportasi umum tersebut. Usaha rumah makan tidak akan dapat menggatikan usaha transportasi yang sama-sama dibutuhkan wisatawan. Oleh sebab itu usaha-usaha pariwisata disebut tidak dapat saling menggantikan. Masyarakat dalam hal ini juga perlu untuk bekerja sama agar pekerjaan-pekerjaan yang sulit dapat terasa ringan dan yang ringan akan semakin ringan. Kerja sama ini juga akan mempererat kekeluargaan pada masyarakat lokal. Sejauh ini pengelola di Daya Tarik Wsata Hutan Pinus sudah menjalin kerja sama dalam lingkup pengelola yang aktif saat ini saja. Namun perlu adanya kerja sama yang lebih luas dengan semua elemen masyarakat lokal serta pemerintah desa. Selain itu perlu adanya kerjasama yang bersifat pentahelix yang melibatkan unsur pemerintah, industri atau pelaku usaha pariwisata lainnya, media, akademisi dan stakeholder lainnya yang terkait agar daya tarik wisata ini semakin berkembang dan maju. 
Peningkatan partisipasi Masyarakat yang sangat krusial dalam pengelolaan daya tarik wisata perlu dilakukan dengan cara Pemerintah desa dan pemerintah kabupaten dapat bekerja sama untuk mendampingi dan mengarahkan masyarakat desa Dulamayo Selatan dalam membangun daya tarik wisata hutan pinus. Selanjutnya pemerintah perlu mengumpulkan semua elemen masyarakat di Desa Dulamayo Selatan dengan melibatkan smua perwakilan dusun di desa tersebut untuk melakukan musyawarah dan memberikan mereka kebebasan dalam mengutarakan ide dan pendapat dalam rangka membangnun pariwisata di desanya. Dalam pengelolaan daya tarik wisata khususnya pengelolaan keuangan dilakukan secara transparansi dan akuntable. Dalam pengelolaan daya tarik wisata hutan pinus perlu dikelola dengan menyetarakan kewenangan dan juga memberi tanggung jawab yang sama kepada semua pihak agar dapat tercita rasa kepemilikan secara bersama-sama terhadap daya tarik wisata tersebut. semua masyarakat desa harus tercover dan diberdayakan dan melakukan berbagai aktifitas secara gotong royong atau bekerja sama sehingga mereka dapat merasakan keuntungan secara bersamasama pula serta rasa kekeluargaan akan tetap terpupuk di desa itu.

\section{KESIMPULAN}

Masyarakat merupakan unsur terpenting dalam suatu destinasi. Masyarakat juga merupakan stakeholder yang sangat dibutuhkan perannya apalagi pada pariwisata pedesaan dan desa wisata. Tidak heran mengapa ada konssep daya tarik wisata berbasis masyarakat. Dari sinilah terlihat jelas pentingnya peranan masyarakat lokal pada suatu daya tarik wisata. Berdasarkan hasil penelitian pada Daya Tarik Wisata Hutan Pinus Dulamayo Selatan, keterlibatan masyarakat lokal secara keseluruhan belum diimplementasikan. Pada hal potensi desa dapat dimanfaatkan seluruh warga desa untuk mencapai kesejahteraan melalui pembangunan pariwisata berkelanjutan yang berbasis masyarakat. Masyarakat perlu bergotong royong dalam membangun, mengelola dan mengembangkan potensi desa sebagai suatu daya tarik yang keuntungannya dapat dirasakan dan dinikmati bersamasama. Tidak adanya partisipasi masyarakat secara keseluruahan akan dapat memicu berbagai problematika. Oleh karena itu pemerintah dapat mengarahkan warga masyarakat lokal agar dapat berpartisipasi dan melakukan aktifitas usaha dalam bidang pariwisata..

\section{REFERENSI}

Abdillah, 2016. Dampak pengembangan pariwisata terhadap kehidupan masyarakat lokal .Universitas Brawijaya. Malang.

Hajar, Siti dkk. 2018. Pemberdayaan dan Partisipasi Masyarakat Pesisir. Lembaga Penelitian dan Penulisan Ilmiah Aqli. Medan

Mulyadi. 2003. Ekonomi sumber daya manusia. Jakarta : Raja Grafindo Persada. 
Shantika, 2018.Dampak perkembangan pariwisata terhadap kondisi social ekonomi mayarakat di pulau Nusa Lembongan.Universita Udayana. Denpasar

Sugiyono. 2009. Metode Penelitian Bisnis. Bandung: Alfabeta

Suwantoro Gamal. 1997. Dasar - dasar pariwisata. Penerbit Andi Yogyakarta.

Undang - undang Nomor 10 Tahun 2009 tentang Kepariwisataan. 